\title{
DIREITOS DA PERSONALIDADE NA SOCIEDADE DA INFORMAÇÃO: O DIREITO AO ESQUECIMENTO
}

\author{
Cristofer Paulo Moreira Rocha Silva \\ Centro Universitário Newton Paiva, Minas Gerais \\ cristofer_paulo@outlook.com \\ Michael César Silva \\ Centro Universitário Newton Paiva, Minas Gerais \\ michael@adv.oabmg.org.br
}

\begin{abstract}
RESUMO: No cenário contemporâneo, em que se manifesta a sociedade da informação, fruto de revoluções tecnológicas, verifica-se o uso, cada vez maior, das mídias, difundindo-se, maciçamente, diferentes informações, sejam estas positivas ou negativas; agradáveis ou não. Ademais, com a possibilidade de armazenamento de dados, preserva-se a identidade de acontecimentos, de modo que é plenamente possível que os fatos ressurjam, a qualquer tempo. Neste contexto, constata-se a carência da proteção das pessoas e a preservação da dignidade humana, vindo à tona o direito da personalidade ao esquecimento. Deste modo, o problema da pesquisa se revela na análise crítica da (im)possibilidade de aplicação deste direito, bem como os conflitos que enfrenta com outros direitos fundamentais, como a liberdade de expressão. O objetivo da pesquisa é analisar os contornos do direito ao esquecimento, sob as lentes do Direito Civil contemporâneo, bem como, estabelecer seus limites e contornos. O método utilizado é o indutivo, o qual viabiliza a adoção da linha crítico metodológica, na medida em que se desenvolverá um estudo bibliográfico, sendo possível alcançar uma conclusão mais ampla que as premissas, em razão da análise crítica dos materiais.
\end{abstract}

PALAVRAS-CHAVE: Direitos da personalidade. Direito ao esquecimento. Sociedade da informação.

\section{Personality rights in the information society: the right to be forgotten}

ABSTRACT: In the contemporary scenario, in which the information society is manifested, as a result of technological revolutions, there is an increasing use of media, massively spreading differents informations, whether positive or negative; pleasant or not. Furthermore, with the possibility of data storage, the identity of events is preserved, so that it is entirely possible for facts to resurface, at any time. In this context, there is a lack of protection for people and the preservation of the human dignity, with the personality's right to be forgotten. Thus, the research problem is revealed in the critical analysis of the possibility or not of applying this right, as well as the conflicts it faces with other fundamental rights, such as freedom of expression. The objective of the research is to analyze the contours of the right to be forgotten, under the lenses of contemporary Civil Law, as well as to establish it's limits and contours. The method used is the inductive one, which enables the adoption of the critical methodological line, as a bibliographic study will be developed, being possible to reach a broader conclusion than the premises, due to the critical analysis of the materials.

KEYWORDS: Personality rights. Right to be forgotten. Information society. 


\section{INTRODUÇÃO}

A contemporaneidade foi forjada pelo incremento de equipamentos e instrumentos tecnológicos, em especial, após a Segunda Guerra Mundial, com o advento da terceira revolução tecnológica, que possibilitaram novas formas de se comunicar, sendo viabilizada a difusão de informações, recebidas pelos pares, quase que instantaneamente.

Nesta esteira, tem-se constituída a sociedade da informação, a qual disfruta as benesses da tecnologia, ao passo que enfrenta inúmeros problemas, em especial, a exposição da pessoa humana a danos, como aqueles perpetrados em desfavor de sua personalidade.

Encontra-se, neste contexto, como desdobramento das revoluções tecnológicas, a possibilidade de armazenamento de dados e a preservação da identidade de acontecimentos, viabilizando que um fato do passado seja colocado na pauta do dia, rememorando a sociedade, a família e os amigos do envolvido, bem como o próprio protagonista do episódio.

Nesta pegada, discute-se, entre os direitos da personalidade, o direito ao esquecimento, o qual se apresenta com o objetivo de resguardar a personalidade humana, de modo a evitar que os eventos do passado ressurjam, sem qualquer critério, com potencialidade de gerar danos a dignidade dos envolvidos.

Diante do exposto, a pesquisa apresenta como problema a (im)possibilidade de aplicação do direito ao esquecimento, em especial, na hipótese de ocorrência de conflito com outros direitos fundamentais, tais como a liberdade de imprensa, a liberdade de informação, a liberdade de expressão, dentre outros.

O objetivo da pesquisa encontra-se em explicitar o contexto da sociedade da informação, a importância dos direitos da personalidade, o significado e fundamento do direito ao esquecimento, bem como analisar os conflitos que este direito enfrenta com outros interesses constitucionais, em especial, os direitos comunicativos, com a finalidade de indicar critérios que possam vir a ser aplicados pelos magistrados.

Inicialmente, será apresentado o contexto da sociedade da informação. Em sequência, debater-se-á os direitos da personalidade de forma geral, demonstrando sua origem, bem como a proteção jurídica contemporânea. Em outro tópico, o direito ao esquecimento será abordado, oportunidade em que se melhor apresentará o seu conceito, finalidade, embasamento jurídico, além de críticas a este direito. Em sequência, serão apresentados dois casos paradigmáticos sobre direito ao esquecimento, julgados no Superior Tribunal de Justiça. Por fim, será debatida a possibilidade de aplicação do direito ao esquecimento.

A pesquisa adota o método indutivo, o qual tem como objetivo ampliar o alcance dos conhecimentos, se caracterizando por "um processo mental que parte de dados particulares e localizados e se dirige a constatações gerais. Assim, as conclusões do processo indutivo de raciocínio são sempre mais amplas do que os dados ou premissas dos quais derivam". (GUSTIN; DIAS, 2013, p. 22). A escolha de tal método se deve, em especial, a possibilidade de a conclusão ser mais ampla, o que seria inviável se, por exemplo, fosse adotado o método dedutivo. Desta forma, é possível a adoção da linha crítico metodológica, de forma que se analisará a realidade das decisões judiciais, bem como dos escritos doutrinários, com a devida criticidade e argumentação. A técnica adotada é a bibliográfica. A opção metodológica da pesquisa, ainda, passa pelo procedimento jurídico-descritivo, a ponto de investigar os problemas jurídicos em torno da temática, apresentando um potencial explicativo e propositivo. 


\title{
1. DA SOCIEDADE DA INFORMAÇÃO
}

$\mathrm{O}$ advento das revoluções tecnológicas mudou, significativamente, o modo pelo qual as pessoas vivem, desenvolvem suas atividades, se relacionam. Toda esta alternância de paradigma encontra influência do desenvolvimento tecnológico e científico do século XX e da primeira década do século XXI, o qual obtém síntese e auge na Internet, com inventos de ponta, envolvendo diversas áreas da ciência, desenvolvendo poderosos computadores, aprimorando a comunicação, com emissão e transmissão de som e imagens por cabos, fibra ótica, rádio e satélites (CAVALIERI FILHO, 2019, p.174). Fato é que, aquilo que outrora era inimaginável de ser concretizado, foi criado, vem sendo aprimorado, restando a incerteza e a curiosidade do que pode ser desenvolvido nos próximos anos.

\begin{abstract}
A contemporaneidade é marcada por profundas transformações impulsionadas pelas novas tecnologias da informação e da comunicação atingindo, indistintamente, todos os setores da sociedade. Essas transformações têm produzido inovações nas práticas no cotidiano, nos estilos de vida, na esfera comunicativa e, cada vez mais, na forma de ensinar e aprender (MARQUES; CRESPO, 2015, p. 123).
\end{abstract}

Ante todo esse desenvolvimento tecnológico, as informações alcançam um elevado grau democrático, retratado no fato de que considerável número de pessoas as tem à sua disposição e as utilizam constantemente, gozando o acesso facilitado pela Internet, a qual é repleta de funções $^{1}$, permitindo o consumo de notícias, redes sociais ${ }^{2}$, publicidades, trocas de mensagens, os quais apresentam recursos diversos, como de fotos, de vídeos, de textos, os quais pautam e marcam a vida dos atores sociais.

Logo, a Internet apresenta indiscutível relevância, particularmente, pelo fato de que "contribui para o desenvolvimento político, econômico e social, permitindo uma sociedade mais bem informada e capaz de fazer sua voz ser ouvida de maneira muito mais eficaz do que antes do seu advento" (COLNAGO, 2019, p.255).

Destarte, manifesta-se, no contexto contemporâneo, a sociedade da informação, determinada, especialmente, pela influência de cargas informativas distintas, que afetam a economia, a política e a sociedade como um todo. A sua principal "característica é a facilidade de acesso a informações em tempo quase que real, de forma jamais vista na história da tecnologia. Denotase que a informação é o centro gravitacional desta nova era" (BARRETO JÚNIOR; SAMPAIO; GALLINARO, 2018, p.114).

Essa sociedade da informação apresenta fatores positivos, como uma comunicação de ponta, troca de dados pessoais e profissionais, informações sobre trânsito, sobre locais para serem visitados, não obstante, deve-se destacar que

As possibilidades tecnológicas proporcionaram grande acesso à informação, mas pouco controle no seu uso, deixando até as instituições públicas internas e externas incapazes de conter todo esse aparato tecnológico e suas novas formas de coleta e de

1 Eduardo Mingorance de Freitas Gouvêa (2019, p. 30) destaca que: “A Internet possui várias funções para os seus usuários, as mais conhecidas são: sites de busca (exs.: Google, Yahoo!, Bing); correios eletrônicos (e-mails); redes sociais virtuais (exs.: Facebook, Twitter, Instagram); mensagens instantâneas (exs.: WhatsApp, iMessage, Viber), videoconferência (ex.: Skype, FaceTime); plataforma de reprodução de vídeo e filmes (exs.: Youtube, Netflix); sites de notícias; comércio eletrônico (e-commerce); chats eletrônicos; voto pela internet; moeda digital (ex.: Bitcoin); entre outros serviços".

2 "Um serviço de rede social (social networking service) é uma plataforma, baseada na internet, para a construção de redes sociais ou relações sociais entre as pessoas que, por exemplo, desejam compartilhar interesses, atividades ou conexões da vida real. Tal serviço consiste em uma representação de cada usuário (geralmente um perfil), suas relações sociais, e uma variedade de serviços adicionais. Desse modo, os sites de redes sociais permitem aos usuários compartilhar ideias, imagens, mensagens, atividades, eventos e interesses com as pessoas em sua rede" (HIRATA, 2014, p. 18). 


\begin{abstract}
tratamento da informação. Nessa era informativa e tecnológica, surgem a sociedade da informação e os desafios para tutelar a privacidade, principalmente quando a informação é usada para entreter a população, transformando, assim, essa sociedade em civilização do espetáculo.

[...] a sociedade da informação, como produto da sociedade pós-industrial, objetivava a concretização das diversas formas de liberdade de expressão, mas trouxe consigo as ameaças e as lesões aos direitos e garantias fundamentais (privacidade, honra, imagem, intimidade) (MOREIRA; MEDEIROS, 2016, p.73-75).
\end{abstract}

Assim sendo, mesmo diante de vastos benefícios ${ }^{3}$, o avanço tecnológico provoca determinada preocupação ${ }^{4}$ quando da análise de seus reflexos, sendo perceptível o estado de vulnerabilidade da pessoa humana, proporcionado no contexto da sociedade da informação, coexistindo a possibilidade de uma série de risco de dano à pessoa e aos seus direitos, de tal modo que se torna "imperiosa a incidência dos direitos fundamentais nas relações interprivadas digitais, promovendo-se um necessário update dos direitos da personalidade, de modo a permitir que possam rodar em um sistema operacional compatível com os valores constitucionais" (SCHULMAN, 2016, p.339).

Portanto, é reconhecível o quanto os instrumentos tecnológicos agregaram para o corpo social, desenvolvendo-se o paradigma da sociedade da informação, não obstante, este contexto contemporâneo requer que não se olvide que a pessoa humana é um sujeito de direitos, de modo a lhe ser destinada a proteção adequada, sendo necessário aplicar as disposições do Estado Democrático de Direito, em consonância como os princípios e valores trazidos pela Constituição Federal de 1988.

\title{
2. HISTÓRICO E IMPORTÂNCIA DOS DIREITOS DA PERSONALIDADE
}

Em que pese alguns autores situarem o marco inicial dos direitos da personalidade na antiguidade, na Grécia, com as dike kakegorias, e em Roma, com a actio injuriarum (SAMPAIO, 1998, p.48), somente "com o cristianismo e a pregação de uma fraternidade universal, tem início um despertar para a proteção da personalidade humana” (FARIAS; ROSENVALD, 2016, p.174), de modo que foi por meio do evangelho, em que se destacam ensinamentos no sentido de amar ao próximo, quando Jesus de Nazaré concretizou um modelo ético de pessoa, tornando aos homens mais acessível a sua imitação (COMPARATO, 2008, p.17-18), que se originou a "força que fez com que a figura do homem (até então mitigada) fosse elevada à posição de pessoa dotada de subjetividade de maneira efetiva" (CONSALTER, 2017, p, 35).

No entanto, é importante escancarar que essas mudanças, desencadeadas pelo surgimento do cristianismo, foram gradativas, de modo que:

[...] foi particularmente na Idade Média que surgiram, com maior concretude, ideias de valorização do homem, reconhecendo-se nele intrínseco um componente espiritual, mais que corpóreo, cuja significação está em sua dignidade, base da concepção dos direitos da personalidade (GODOY, 2015, p. 9)

Logo, foi a partir da Idade Média que se percebe uma maior atuação em favor da proteção dos direitos da personalidade, sendo possível observar esse comportamento com a edição da

\footnotetext{
3 Por tratar em benefícios, é válido o destaque de Jânio Urbano Marinho Júnior (2018, p. 19), o qual defende que: “podese extrair uma visão positiva desse cenário, uma vez que onde há excesso de informação há liberdade de expressão, valor essencial para o fortalecimento da democracia. Aliás, direito fundamental expressamente consagrado na Constituição de 1988, em diversos de seus incisos".

4 Neste sentido, Marcos Ehrhardt Júnior e Bruno de Lima Acioli (2019, p. 160) expõem que "se os louros dos recentes avanços tecnológicos para a humanidade são amplamente notáveis, não raro este progresso tecnoeconômico é recebido com gigantesca desconfiança".
} 
Carta Magna inglesa em 1215, garantindo, dentre outros direitos, a liberdade; com a Declaração dos Direitos do Homem e do Cidadão em 1789; a Declaração Universal dos Direitos Humanos em 1948, após a Segunda Guerra Mundial; bem como o Pacto de San José da Costa Rica, em 1969.

Tendo em vista esse amadurecimento do Direito, em caráter global, o Brasil não ficou alheio, se adequando a estas mudanças, especialmente, com a promulgação, em 5 de outubro de 1988, de uma Constituição Federal, extremamente sensível e preocupada com a proteção das pessoas, redirecionando o Direito para aplicar princípios, direitos e garantias fundamentais, a fim de que se preserve a dignidade da pessoa humana.

\begin{abstract}
[...] o princípio da dignidade, que tem campo de incidência extremamente amplo, vincula o Estado e os particulares e envolve prestações positivas e negativas. Ele desempenha múltiplas funções em nosso ordenamento: é fundamento moral do Estado e do Direito, diretriz hermenêutica de todo o sistema jurídico, norte para a ponderação de interesses, parâmetro de validade dos atos estatais e privados, limite para o exercício de direitos, critério para a identificação de direitos fundamentais e fonte de direitos não enumerados na Constituição. A dignidade humana é assegurada através dos direitos positivados na Constituição, mas também por meio da incidência direta do princípio da dignidade sobre a ordem jurídica e relações sociais. (SARMENTO, 2016, p.98 $)^{5}$
\end{abstract}

Nessa linha de raciocínio, conforme salienta Luiz Edson Fachin (2019, p.368), o texto constitucional incorporou "uma série de direitos fundamentais corolários do princípio da dignidade humana no que diz respeito ao livre desenvolvimento da personalidade, posse e propriedade, vínculos familiares, responsabilização civil, complexos contratuais".

A partir da influência dos preceitos e valores constitucionais, o Direito Civil assumiu novos contornos, passando por um processo denominado de constitucionalização do Direito Civil, na medida em que se deixa de olhar para a Constituição com as lentes do Estado mínimo, em que a Constituição se valia simplesmente para estabelecer a organização do Estado, bem como a não interferência do Estado na esfera privada, passando a assumir o papel de promotora de direitos e garantias fundamentais ${ }^{6}$, emanando mandamentos para todo o ordenamento jurídico, inclusive para a seara privada, que deverá se adequar aos valores e princípios constitucionais ${ }^{7}$.

5 Antonio Junqueira Azevedo (2002, p. 123) explicita que "a dignidade da pessoa humana como princípio jurídico pressupõe o imperativo categórico da intangibilidade da vida humana e dá origem, em sequência hierárquica, aos seguintes preceitos: 1 . respeito à integridade física e psíquica das pessoas; 2 . consideração pelos pressupostos materiais mínimos para o exercício da vida; e 3. respeito às condições mínimas de liberdade e convivência social igualitária". Neste sentido ver: Farias; Rosenvald; Braga Netto (2019, p.42-49); Wolfgang Sarlet (2015); Barroso (2014).

6 Ingo Wolfgang Sarlet (2017, p. 66) leciona que "Na CF, além da inserção da dignidade da pessoa humana como princípio (e valor) fundamental e estruturante da ordem constitucional (art. $1^{\circ}$, III), situando-a (...) no início do texto constitucional, também os direitos fundamentais alcançaram um papel de destaque ímpar e sem precedentes no constitucionalismo brasileiro anterior, seja do ponto de vista qualitativo (pelo grande número e diversidade de direitos positivados), seja na perspectiva qualitativa, em especial pelo regime jurídico reforçado atribuído aos direitos fundamentais pelo constituinte e, na evolução posterior, pela doutrina e jurisprudência".

7 Sobre o fenômeno abordado, César Fiuza (2008, p. 66) afirma que: "Por constitucionalização do Direito Civil devese entender, hoje, que as normas de Direito Civil têm de ser lidas à luz dos princípios e valores consagrados na Constituição, a fim de se implementar o programa constitucional na esfera privada. A bem da verdade, não só as normas de Direito Civil devem receber leitura constitucionalizada, mas todas as normas do ordenamento jurídico, sejam elas de Direito Privado, sejam de Direito Público. Esse é um ditame do chamado Estado Democrático de Direito, que tem na Constituição sua base hermenêutica, o que equivale a dizer que a interpretação de qualquer norma deverá buscar adequá-la aos princípios e valores constitucionais, uma vez que esses mesmos princípios e valores foram eleitos por todos nós, por meio de nossos representantes, como pilares da sociedade e, consequentemente, do Direito". 
Nessa esteira, com o advento do Código Civil (2002), estabeleceu-se regramento relativo às pessoas naturais, com ênfase a abordagem destinada aos direitos da personalidade ${ }^{8}$, distribuindo-os nos artigos 11 a 21, que expõem algumas das principais características de tais direitos, como a intransmissibilidade e a irrenunciabilidade, além de tratar de atos de disposição do próprio corpo, direito ao nome, direito a imagem, direitos autorais, direito a vida privada.

Superado este breve delineamento e contextualização histórica, faz-se oportuno explorar a definição de direitos da personalidade, os quais são vistos como "direitos que versam sobre a própria pessoa e seus reflexos e que são reconhecidos à pessoa humana e atribuídos à pessoa jurídica" (MORATO, 2012, p.124).

Para Carlos José Cordeiro e Joaquim José de Paula Neto (2015, p.10),

[...] os direitos da personalidade representam de forma direta a irradiação da dignidade da pessoa humana como valor-fonte do ordenamento jurídico brasileiro. Assim, reforça-se a ideia de que o respeito à pessoa e às suas circunstâncias são exigíveis não só contra o Estado, como já era garantido pelos direitos fundamentais na esfera do direito público, mas também contra qualquer ato privado que afronte a dignidade intrínseca a qualquer pessoa.

Logo, os direitos da personalidade concretizam-se como instrumento de tutela da pessoa humana, em um cenário contemporâneo, em que a pessoa assume importante papel para o Direito Civil, abandonando-se a ideia de se voltar tão somente para as questões patrimoniais, e fundado no compromisso de reconhecer que o ser humano, por si só, é um sujeito de direitos, sendo este o foco central dos direitos da personalidade, que se inserem "no âmbito das situações subjetivas existenciais, as quais se diferem fundamentalmente das patrimoniais na medida em que cuidam da tutela jurídica da pessoa, e não dos bens materiais por ela titularizados” (NEVES, 2019, p.7).

No contexto do Estado Democrático de Direito, trazido pela Constituição Federal de 1988, no qual é fundamental que se atente para a aplicação e para o cumprimento de princípios, como o da dignidade da pessoa humana, os direitos da personalidade devem ser munidos não só de uma proteção jurídica, mas também de todos "os direitos atinentes à tutela da pessoa humana, considerados essenciais à sua dignidade e integridade” (TEPEDINO, 2008, p. 26).

Diante de todo o exposto, não se pode deixar de esclarecer que:

A definição de direito da personalidade tem base relacional com os direitos e garantias fundamentais e a dignidade da pessoa humana.

Em face dessa base relacional, adota-se o entendimento (...) de que o rol dos direitos da personalidade do Código Civil brasileiro de 2002 (artigos 11 a 21) não é taxativo, mas meramente exemplificativo ("elástico", havendo uma cláusula geral de tutela dos direitos da personalidade que se dá no plano constitucional (artigo $1^{\circ}$, inciso III, da Constituição Federal) a partir do princípio da dignidade da pessoa humana (ALMEIDA; VEDOVATO; SILVA, 2018, p. 44)

À vista disso, admite-se que há uma elasticidade no rol de direitos da personalidade disposto no Código Civil, tendo em vista que a denominação direito da personalidade é um gênero, capaz de incluir várias espécies que encontrem finalidade comum (proteger a dignidade humana), havendo a possibilidade de determinados direitos estarem positivados e outros se desdobrarem da cláusula geral de tutela dos direitos da personalidade, sendo possível o estudo e a aceitação

8 Segundo Taisa Maria Macena de Lima e Maria de Fátima Freire de Sá (2018, p.29): "A inserção do capítulo sobre os direitos da personalidade no Código Civil de 2002 é menos uma inovação do que a consagração da construção doutrinária e jurisprudencial tendente à proteção dos atributos e das projeções da pessoa. Antes da recodificação do direito privado nacional, a Constituição da República de 1988, ao disciplinar os Direitos Fundamentais, mencionou expressamente alguns bens jurídicos existenciais (art. $5^{\circ}$, inciso X) e elegeu a dignidade da pessoa humana como um dos fundamentos da República (art. $1^{\circ}$, inciso III)". 
de outros direitos da personalidade, como o direito ao esquecimento, que será analisado no próximo tópico.

Chiara Spadaccini de Teffé (2019, p. 94-95) sustenta que:

Sendo a personalidade um valor - o valor fundamental do ordenamento -, ela se encontra na base de uma série aberta de situações subjetivas existenciais, nas quais se traduz a sua constante e mutável exigência de tutela. Não parece haver uma série fechada de situações tuteladas: tutelado deve ser o valor da pessoa, com exceção dos limites impostos em razão de seu interesse e de outras pessoas. O intérprete não deve se restringir aos direitos positivados na Constituição Federal e no Código Civil, mas garantir as diversas manifestações existenciais da pessoa, uma vez que essas, em princípio, já gozariam de relevância no ordenamento. Nesse sentido, pode-se afirmar que os direitos da personalidade envolvem os direitos ao próprio corpo, à honra, à intimidade, à privacidade, à integridade, à imagem, ao nome e tudo mais relacionado diretamente ao ser humano que seja digno de proteção e defesa na ordem constitucional.

Todo este estudo estimula a percepção de que, no paradigma do Estado Democrático de Direito, os direitos da personalidade recebem novas cores e contornos, de tal modo que a pessoa humana é qualificada a ter direitos a ela inerentes, sendo aplicável o princípio da dignidade da pessoa humana, com a finalidade de que, independente do seu modo de viver, possa ser respeitada, sendo exigível, no entanto, que também respeite os outros.

\section{LINEAMENTOS SOBRE O DIREITO AO ESQUECIMENTO}

Por certo, alguns direitos surgem em resposta a significativas experiências vividas por determinada sociedade, de modo a partilhar dores, lembranças e lições em comum (BRAGA NETTO, 2019, p. 541). Entre as experiencias que vêm sendo vivenciadas, encontram-se aquelas inerentes a sociedade da informação, sendo perceptível que os avanços da tecnologia expõem a pessoa humana a novas situações que desafiam o ordenamento jurídico (TEPEDINO, 2008, p.2526), como as lesões a personalidade humana, o que instiga o debate sobre a possibilidade da existência de um direito ao esquecimento, amparado no ordenamento jurídico brasileiro.

Este direito pode ser entendido como o "direito de não ser lembrado contra a sua vontade, especificamente no tocante a fatos desabonadores" (FERNANDES, 2016, p.410). Portanto, a pretensão deste direito é "impedir que episódios e fatos do passado ressurjam no presente, atrapalhando a vida de alguém” (FARIAS; BRAGA NETTO; ROSENVALD, 2019, p.923).

Em outros termos, esse direito da personalidade, que recebeu relevo nos últimos anos, torna-se ponto de exame da doutrina, bem como dos tribunais, por condensar o princípio da dignidade da pessoa humana, com outros direitos fundamentais e da personalidade, como o direito à honra, à privacidade, à imagem, a fim de que um sujeito que tenha praticado algum ato no passado, do qual não se orgulha, não venha a ser exposto com recordações do feito, o qual seria fonte de sofrimento e angústia.

Assim, Anderson Schreiber (2019, p. 534) instrui que:

O direito ao esquecimento consiste simplesmente de um direito da pessoa humana de se defender contra uma recordação opressiva de fatos pretéritos que podem minar a construção e reconstrução da sua identidade pessoal, [...] de modo a fornecer ao público uma projeção do ser humano que não corresponde à sua realidade atual. 
Nesse giro, o direito ao esquecimento assume a pretensão de proteger o ser humano de seu próprio passado, dando-lhe, não só a oportunidade de construir novos caminhos, mas, também, de não ser o centro das atenções de um público que não apresenta interesse relevante sobre os fatos da vida de outrem.

\title{
Como exemplo deste direito, encontra-se a
}

\begin{abstract}
[...] hipótese nada incomum da atriz que, em início de carreira, autoriza a veiculação de sua imagem, nua, em dada revista masculina ou atua como personagem de um filme picante. Suponha-se que a mesma atriz, ao longo dos anos seguintes, venha a construir carreira como apresentadora de programas infantis. Não há dúvidas de que a veiculação daquelas imagens do passado, destacadas do seu contexto original, pode causar grave dano à pessoa retratada. Mesmo que a autorização para a veiculação da imagem tenha sido dada na ocasião pretérita, sem qualquer limite temporal (...), resta evidente que a vida da pessoa encaminhou-se em sentido oposto ao daquele ato pretérito (SCHREIBER, 2014, p. 172-173).
\end{abstract}

No caso em tela, figura uma pessoa pública, que alterou a sua imagem ao longo da carreira, tomando um rumo oposto, de modo que se antes era personagem de filme picante para adultos, o seu foco passa a ser as crianças, apresentando programas infantis, não mais sendo conveniente a lembrança de suas atuações de outrora, o que poderia atrapalhar o exercício de seu novo ofício, ou mesmo provocar-lhe certo sofrimento, na hipótese de haver se arrependido daquilo que fez no início da carreira.

Longe de um caso envolvendo uma figura pública, que no passado optou por ser exposta, pode-se imaginar o caso de um estudante que tentou fraudar o sistema de cotas para ingresso em uma Universidade, declarando ser o que não era. A fraude veio à tona, apresentando repercussão nas mídias. $\mathrm{O}$ estudante assume o ônus pelo erro que cometeu e segue o seu rumo, ingressa em outra Universidade, se forma, conquista o seu emprego. Alguns anos depois, publica-se matéria jornalística relembrando que, durante a vigência da política de cotas, alguns sujeitos tentaram fraudá-la, expondo o feito do estudante do caso tratado.

Por esta situação, pode-se ter noção das consequências, pessoais e profissionais, desta matéria jornalística para aquele que fraudou o sistema de cotas, mas assumiu as suas responsabilidades e tentou reconstruir sua vida, estudando, trabalhando, quando, posteriormente, é surpreendido com o seu rosto nas mídias, mostrando, para si, seus familiares, colegas, chefes, o erro que havia cometido outrora.

É errôneo julgar que todo ser humano constrói determinadas características e sempre será assim, pois, em verdade, as pessoas passam por um processo constante de mudanças, muitas em um sentido positivo ${ }^{9}$. É comum encontrar, por exemplo, um idoso que anuncia ter feito coisas em sua juventude que, atualmente, guarda arrependimento. Imagine que esses fatos fossem divulgados, não só para terceiros, mas para o próprio idoso. Tem-se, aí, possivelmente, grande chance de sofrimento, tratando-se de flagrante desrespeito a sua dignidade.

Com isso, entende-se a razão de existir o debate sobre o direito ao esquecimento, que se estrutura em um contexto que as informações fazem parte do cotidiano humano, seja na tela de uma televisão, de um computador ou de um celular. Tudo está ali, podendo voltar à pauta pela escolha, por exemplo, do editor de um jornal. A questão é se seria oportuna a opção deste editor, a qual poderia violar a personalidade do envolvido, sendo urgente considerar a existência do direito ao esquecimento.

9 Nesse sentido, o Ministro Luis Felipe Salomão destacou que "o direito ao esquecimento revela sua maior nobreza, pois afirma-se, na verdade, como um direito à esperança, em absoluta sintonia com a presunção legal e constitucional de regenerabilidade da pessoa humana”. (BRASIL, STJ, REsp 1.334.097/RJ, 2013, p.14). 
Para alguns autores, o direito ao esquecimento seria uma figura híbrida, contemplando o direito a ser esquecido e o direito a esquecer. Nessa linha de intelecção, Rodrigo Pereira Moreira e Rubens Valtecides Alves (2015, p. 90) entendem que o direito ao esquecimento:

[...] pode assumir dois aspectos diferentes - todavia não excludentes - concernentes ao: (a) direito de ser esquecido e (b) direito à esquecer. O primeiro assume uma perspectiva dirigida a terceiros, ou seja, quem deveria esquecer o seu passado. Já o segundo adota uma visão de primeira pessoa, pois é preciso que o ser humano esqueça o seu próprio passado para começar um novo modo de ser e viver.

[...] O direito de ser esquecido está intrinsecamente ligado ao direito à privacidade $\mathrm{e}$ ao direito à honra, enquanto o direito à esquecer deriva do direito à identidade pessoal, pontos de vista complementares na formação do direito ao esquecimento.

Deste modo, ao refletir sobre o direito ao esquecimento, pode-se dividi-lo em dois outros direitos, o primeiro seria o direito a esquecer, em que a própria pessoa quer olvidar o seu passado e seguir em frente, a fim de construir e reconstruir a sua própria identidade, sem que seja atormentada, lembrada, por fato(s) pretérito(s). De outra banda, tem-se o direito de ser esquecido, o qual delineia a ideia de impedir que fatos passados, com menor grau de relevância no presente, possam voltar a pauta, instigando todos a recordarem determinado acontecimento longínquo, podendo violar tanto a privacidade, quanto a honra do envolvido, de modo que parte da sociedade, a qual se inclui as pessoas próximas, inclusive com relações profissionais, reanalisarão os acontecimentos do pretérito.

Seguindo a lógica dos demais direitos da personalidade, o direito ao esquecimento encontra embasamento na cláusula geral da tutela dos direitos da personalidade, qual seja o princípio da dignidade da pessoa humana (Art. $1^{\circ}$, III, CF/88), tendo em vista que pautar eventuais lembranças desnecessárias de fatos do passado pode provocar prejuízos ao envolvido, tanto consigo mesmo, por ter que rememorar os acontecimentos de outrora, mas também com o corpo social, que revive os fatos e naturalmente volta a condenar a ocorrência, com potencial de provocar constrangimento e perdas ao seu autor.

Neste sentido, o Conselho de Justiça Federal, na VI Jornada de Direito Civil, aprovou o enunciado $\mathrm{n}^{\mathrm{o}}$ 531, afirmando que "A tutela da dignidade da pessoa humana na sociedade da informação inclui o direito ao esquecimento" (BRASIL, 2013, p.1). Como justificativa para o Enunciado, o órgão afirma que o direito ao esquecimento " [...] não atribui a ninguém o direito de apagar fatos ou reescrever a própria história, mas apenas assegura a possibilidade de discutir o uso que é dado aos fatos pretéritos, mais especificamente o modo e a finalidade com que são lembrados" (BRASIL, 2013, p. 1).

Destarte, o direito ao esquecimento não apresenta o condão de destruir os fatos do passado, mas evitar que seja incentivada a lembrança, sem critérios, de determinados acontecimentos, que possam vir a gerar danos na pessoa humana.

Ocorre que a aplicação do direito ao esquecimento é contrariada por outros direitos relevantes para o Estado Democrático de Direito, como é o caso da liberdade de expressão, liberdade de imprensa, liberdade de informação, fortemente amparados pela Constituição Federal ${ }^{10}$.

Na segunda metade do ano de 2019, ao julgar a medida cautelar na suspensão liminar 1.248/RJ, o Presidente do Supremo Tribunal Federal, Ministro Dias Toffoli, argumentou que:

\footnotetext{
${ }^{10}$ Por exemplo, Art. $5^{\circ}$ da CF/88: "IV - é livre a manifestação do pensamento, sendo vedado o anonimato; [...] IX é livre a expressão da atividade intelectual, artística, científica e de comunicação, independentemente de censura ou licença; [...] XIV - é assegurado a todos o acesso à informação e resguardado o sigilo da fonte, quando necessário ao exercício profissional" (BRASIL, 1988).
} 
Direitos da personalidade na sociedade da informação: o direito ao esquecimento

[...] o regime democrático pressupõe um ambiente de livre trânsito de ideias, no qual todos tenham direito a voz. [...]

A liberdade de expressão é um dos grandes legados da Carta Cidadã, resoluta que foi
em romper definitivamente com um capítulo triste de nossa história em que esse di-
reito - dentre tantos outros - foi duramente sonegado ao cidadão. Graças a esse am-
biente pleno de liberdade, temos assistido ao contínuo avanço das instituições demo-
cráticas do país. Por tudo isso, a liberdade e os direitos dela decorrentes devem ser
defendidos e reafirmados firmemente (BRASIL, STF, SL 1248 MC/RJ, 2019, p.12).

Por este ângulo, observa-se o quanto a garantia dessas liberdades importam para a República brasileira, bem como para toda a sociedade, representando muito mais que um meio das pessoas se comunicarem, para terem informações sobre diversos fatos, mas, sobretudo, se consubstancia em uma forma de exercício da cidadania, a fim de contribuir para uma democracia mais saudável, com representantes que sabem que estão sendo acompanhados, devendo atuar com lisura a fim de alcançar os objetivos da sociedade.

\begin{abstract}
A liberdade de expressão faz parte da tradição constitucional brasileira desde a Constituição do Império, com tristes hiatos, porém, durante o governo Vargas e, mais tarde, na ditadura militar, nos chamados anos de chumbo. Nos nossos dias, a Constituição de 1988 valoriza a liberdade de imprensa. É atividade preciosa na construção do pluralismo e do debate de ideias, essenciais a democracia. O Brasil muito deve à imprensa. Certamente não teríamos avançado no combate à corrupção, na depuração de certas práticas políticas nefastas, na fiscalização dos atos de interesse público sem sua decisiva vigilância (BRAGA NETTO, 2016, p. 398-399).
\end{abstract}

Indubitavelmente, todas essas liberdades, que vêm sendo abordadas, demonstram papel fundamental em uma sociedade da informação, a qual busca manifestar suas insatisfações, alegrias, acompanhar o cotidiano alheio, manter-se informada dos acontecimentos hodiernos, ler e dar opiniões, tudo isto contribuindo para a personalidade dos atores sociais, bem como com o seu envolvimento com questões importantes para a democracia, como a política e as instituições do Estado.

Em que pese essas liberdades consubstanciarem significativos direitos para os cidadãos, de lado, aparentemente, oposto encontra-se o direito ao esquecimento, igualmente amparado pelo texto constitucional, como no princípio da dignidade da pessoa humana, nos direitos à intimidade, à vida privada, à honra, à imagem (Art. $\left.5^{\circ}, \mathrm{X} . \mathrm{CF} / 88\right) .{ }^{11}$

Inclusive, o Artigo 220 da CF/88, afirma que: “A manifestação do pensamento, a criação, a expressão e a informação, sob qualquer forma, processo ou veículo não sofrerão qualquer restrição, observado o disposto nesta Constituição" (BRASIL, 1988).

Logo, a Constituição Federal preserva essas liberdades, impedindo que haja restrições, no entanto, admite que, excepcionalmente, em razão de suas próprias disposições, essas liberdades sejam mitigadas $^{12}$, o que pode ocorrer, por exemplo, no caso de aplicação do direito ao esquecimento, o qual encontra base no próprio texto constitucional. Este fato retrata uma das características dos direitos fundamentais e da personalidade, qual seja a relatividade, de modo que a análise do caso concreto deverá concluir qual direito deve sobressair, considerando o contexto constitucional, bem como princípios, tal como o da dignidade da pessoa humana.

11 “Art. 5 X CF/88: são invioláveis a intimidade, a vida privada, a honra e a imagem das pessoas, assegurado o direito a indenização pelo dano material ou moral decorrente de sua violação" (BRASIL, 1988).

12 “[...] afirma-se com todas as letras que, não obstante a Carta estivesse rompendo com o paradigma do medo e da censura impostos à manifestação do pensamento, não se poderia hipertrofiar a liberdade de informação, doravante garantida, à custa do atrofiamento dos valores que apontam para a pessoa humana” (BRASIL, STJ, REsp 1.335.153/ RJ, 2013, p. 22). 
Nesse mesmo giro, Gina Vidal Marcílio Pompeu e Inês Mota Randal Pompeu (2019, p.271) destacam que:

\begin{abstract}
A essencialidade dos direitos fundamentais supracitados - liberdade de expressão e direitos da personalidade - é fato incontroverso. Todavia, apesar disso e tendo por base o princípio da unidade constitucional, e consequente isonomia entre os direitos constitucionais, há situações em que um deles terá de ceder espaço para outro, a depender das circunstâncias de cada caso concreto. Tem-se então o conflito entre direitos fundamentais, cenário tão comum entre as searas da liberdade de expressão e dos direitos da personalidade.
\end{abstract}

Destarte, a livre manifestação necessita de compatibilizar-se com a ordem jurídica global, de modo a se realizar uma interpretação sistemática, a fim que a ponderação encontre guarida no princípio da dignidade da pessoa humana (ROCHA; LOPES, 2016, p. 81).

Outro contraponto ao direito ao esquecimento, que deve ser analisado quando da ponderação, é o direito à memória ou direito à verdade histórica, de modo que a "memória de um povo deve fazer parte todo e qualquer fato relevante que informa e constrói a sua identidade" (CONSALTER, 2017, p. 311). Portanto, este direito recebe especial atenção por apresentar um interesse público relevante, de modo que se torna uma referência para toda a sociedade, como ocorre, por exemplo, no período de ditadura militar, no Brasil, ente 1964 e 1985, influenciando na história do povo brasileiro, devendo fazer parte da memória, inclusive para fins de aprendizado.

Assim, verifica-se que o direito ao esquecimento alcança destaque na sociedade da informação, atuando em consonância com os direitos fundamentais e direitos da personalidade, além de encontrar resguardo no princípio da dignidade da pessoa humana, sendo meio essencial de tutelar uma pessoa que eventualmente possa ser atormentada, contra a sua vontade e sem quaisquer critérios, por fatos desabonadores do passado. Entretanto, este direito enfrenta conflito com determinadas liberdades, como a de expressão, a de informação, a de imprensa, bem como com relação ao direito a memória, o que acarreta a necessidade de analisar a (im)possibilidade de aplicação deste direito, com base na ponderação de interesses.

\title{
4.1. Críticas ao direito ao esquecimento
}

Em que pese haver argumentos favoráveis ao direito ao esquecimento, este não se encontra inatingível por críticas, como aquelas realizadas por Denise Pinheiro e João dos Passos Martins Neto (2018, p. 47), em que se destaca a afirmação de que:

\begin{abstract}
É improcedente afirmar que o reconhecimento do direito ao esquecimento não prejudicará a dimensão coletiva, que a memória e a história restarão íntegras, e que as liberdades de expressão, artística e científica não serão violadas. Tal argumento fundamenta-se na premissa de que o direito ao esquecimento tutela o indivíduo, atingindo tão somente fatos destituídos de interesse público. Contudo, não existe história apenas com "personagens principais" e circunscrita aos "grandes feitos". É inadmissível cogitar de verdades absolutas ou endossar uma história oficial, bem como limitar narrativas, impondo a supressão de fatos, nomes e imagens sob o argumento de que um dado evento não tem caráter histórico ou de que o relato alcança personagens periféricos.
\end{abstract}

De fato, o reconhecimento do direito ao esquecimento provocaria prejuízos a liberdade de expressão, artística, não obstante, deve-se questionar qual o custo de uma liberdade de expressão que seja ampla em todas as temáticas.

Em resposta, parte do custo seria violações ao direito da personalidade do indivíduo, com redução de sua dignidade, de sua honra e, muitas das vezes, o desincentivando a ter melhores 
condutas, já que, independente do que faça, sempre será lembrado por aquele episódio que não se orgulha, podendo desenvolver, inclusive, dificuldades de conviver em sociedade.

Ademais, aqueles eventos realmente históricos, excluídos aqueles em que se tem uma exploração midiática para fins de conquistar audiência, são dotados de interesse público, não podendo deixar de serem retratados, em que pese, ser o mais adequado, quando o sujeito deseja se ver esquecido e esquecer algum acontecimento, podendo os fatos serem expressos sem o expor, que o direito ao esquecimento seja aplicado, tendo em vista que "embora ninguém tenha direito de apagar os fatos, deve-se evitar que uma pessoa seja perseguida, ao longo de toda a vida, por um acontecimento pretérito" (DELPUPO, 2018, p.199).

É necessário, muitas das vezes, deixar de lado a ideia de que vale a pena o prejuízo de um para que haja um suposto benefício de uma coletividade. A convivência em sociedade, no século XXI, demanda sensibilidade dos atores sociais, ao ponto de perceber que determinados assuntos prejudicam alguém e este prejuízo é de difícil reparação, de modo a se verificar, naquela situação, a conveniência de renunciar determinado direito em benefício do outro, poupando-lhe sofrimento. O que se torna possível, graças a característica da relatividade, encontrada nos direitos fundamentais e nos direitos da personalidade.

Sergio Cavalieri Filho (2019, p.175), também, aborda contrapontos ao direito ao esquecimento, instruindo que:

Forte corrente doutrinária e jurisprudencial entende que a retirada dessas informações da internet atenta contra a liberdade de expressão e de informação, pelo que se opõe à tese do direito ao esquecimento. Em linhas gerais, as principais assertivas utilizadas podem ser assim resumidas: (i) o acolhimento do chamado direito ao esquecimento constitui atentado à liberdade de expressão e de imprensa; (ii) o direito de fazer desaparecer as informações que retratam uma pessoa significa perda da própria história, o que vale dizer que o direito ao esquecimento afronta o direito à memória de toda $\mathrm{a}$ sociedade; (iii) cogitar de um direito ao esquecimento equivale a dizer que a privacidade é a censura do nosso tempo; (iv) o direito ao esquecimento teria o condão de fazer desaparecer registros sobre crimes e criminosos perversos, que entraram para a história social, policial e judiciária, informações de inegável interesse público; (v) quando alguém se insere em um fato de interesse coletivo, mitiga-se a proteção à intimidade e privacidade em benefício do interesse público e, ademais, uma segunda publicação (a lembrança, que conflita com o esquecimento) nada mais faz do que reafirmar um fato que já é de conhecimento público.

Como dito alhures, de fato, com o reconhecimento do direito ao esquecimento, outros direitos e liberdades necessitam de uma adequação e, dependendo da situação fática, serem mitigados, a fim de que se caminhe para um norte orientado pela Constituição, qual seja a garantia de que seja implementado, em todas as relações jurídicas, o programa constitucional de promoção da dignidade humana, de tal modo que cada caso oportunizará a análise de qual direito deve prevalecer.

Ademais, o direito ao esquecimento não tem a pretensão de fazer desaparecer informações, pois, estas já foram difundidas no momento adequado. Logo, o que se pretende é evitar que, sendo possível, se exponha uma pessoa, a seu contragosto, relacionando-a com um acontecimento pretérito, podendo causar danos ao envolvido. Nesta acepção, Zilda Mara Consalter (2017, p. 181-182) enfatiza:

Quanto a este direito, antes de mais nada, é bom salientar que ele não se coaduna com a ideia de apagar fatos do passado de alguém (até porque isto parece impossível atualmente) $[\ldots]$

Trata-se, sim da conduta e da forma como serão aqueles utilizados/explorados no futuro, de modo a evitar que o seu titular tenha qualquer tipo de prejuízo, constrangimento, tristeza ou dissabores por fatos/atos perpetrados em seu passado. 
Quanto a um dos últimos argumentos apontado por Sergio Cavalieri Filho (2019, p.175), que indica que uma segunda publicação apenas reafirmaria aquilo que já é de conhecimento público, deve ser visto com muito cuidado. Realmente, quando se retorna à pauta uma discussão travada outrora, possivelmente muitos serão excitados a rememorar o fato, outros, por vários fatores, nem o conheciam. Certo é que, mesmo que estivesse armazenado na memória de todos, as pessoas aprenderam (ou se acostumaram) a conviver com aquele acontecimento, sendo que o próprio autor do fato caminha para reconstruir novas linhas em sua existência, não sendo viável, em alguns casos, especialmente, na hipótese em que não há interesse público ou o envolvimento da pessoa na situação foi apenas acessório, de rememorar, ou mesmo, de expor a pessoa humana a essa nova situação.

\title{
5. O DIREITO AO ESQUECIMENTO NO SUPERIOR TRIBUNAL DE JUS- TIÇA: CASOS PARADIGMÁTICOS
}

No dia 28 de maio de 2013, o Superior Tribunal de Justiça (STJ) analisou, pela primeira vez, dois casos tratando expressamente do direito ao esquecimento, oportunidade em que julgaram o caso da Chacina da Candelária (REsp n. 1.334.097/RJ), bem como o caso da Aída Curi (REsp n. 1.335.153/RJ). Os casos, atualmente, aguardam julgamento do Supremo Tribunal Federal. A fim de contribuir para o debate, em sequência, serão demonstrados os dois casos e como se deu a decisão do STJ.

\subsection{Caso Chacina da Candelária}

O Recurso Especial n. 1.334.097/RJ, de relatoria do Ministro Luis Felipe Salomão, no âmbito do STJ, decorre de ação pleiteando reparação de danos morais, ajuizada por J. G. F. em face da TV Globo Ltda.

A emissora de televisão aproveitando-se do fato de que, em 1993, J. G. F. ter sido indiciado como coautor/partícipe de uma sequência de homicídios intitulada de Chacina da Candelária, a qual foi absolvido por negativa de autoria por unanimidade dos membros do Conselho de Sentença do Tribunal do Júri, procurou o autor a fim de entrevistá-lo e exibir a matéria no "Programa Linha Direta - Justiça". A entrevista foi negada, sendo apresentado desinteresse, por parte de J. G. F., em ter sua imagem exposta.

Ocorre que em junho de 2006, o programa foi ao ar, veiculando J.G.F. como um dos envolvidos na chacina. Esta nova exposição, conforme o autor, reacendeu

\begin{abstract}
[...] na comunidade onde reside a imagem de chacinador e o ódio social, ferindo, assim, seu direito à paz, anonimato e privacidade pessoal, com prejuízos diretos também a seus familiares. Alega que essa situação o prejudicou sobremaneira em sua vida profissional, não tendo mais conseguido emprego, além de ter sido obrigado a desfazer-se de todos os seus bens e abandonar a comunidade para não ser morto por "justiceiros" e traficantes e também para proteger a segurança de seus familiares (BRASIL, STJ, REsp 1.334.097/RJ, 2013, p. 6).
\end{abstract}

Ajuizada a ação, em primeira instancia, o pedido de J. G. F. foi julgado improcedente. Em segunda instancia, o Tribunal de Justiça do Estado do Rio de Janeiro reformou a sentença, destacando que o dever de informar deve se dar no interesse do cidadão e do país, sendo que episódios históricos se revelam patrimônio do povo, podendo a imprensa abordá-los indefinidamente; que a informação pode ser restrita pelo princípio da dignidade da pessoa humana e do direito de todo cidadão em alcançar a felicidade, em especial, no que toca àqueles que, antes 
anônimos, foram absolvidos em processo criminal e retornaram ao esquecimento; que se o autor foi envolvido em caráter lateral e acessório, em caso que foi absolvido, e posteriormente voltou ao anonimato, sendo possível contar a estória da Chacina da Candelária sem menção ao seu nome, tratando-se de um abuso de direito a sua exposição, bem como, havendo a violação da imagem do cidadão que manifestou expressamente que pretendia prosseguir no esquecimento; a TV Globo foi condenada ao pagamento de $\mathrm{R} \$ 50.000,00$ (cinquenta mil reais) como indenização (RIO DE JANEIRO, TJRJ, AC 2008.001.48862, 2008, p. 1-2).

Em sequência, foi submetido ao STJ, Recurso Especial, por parte da TV Globo, argumentando que não houve invasão à privacidade e intimidade de J. G. F., em razão de que os fatos expostos já eram públicos e fartamente discutidos em sociedade, sendo parte do acervo histórico do povo, havendo relevante interesse público, não dirigindo ofensas ao autor, e, inclusive, expondo que este havia sido inocentado. Adverte, ainda, que não seria possível retratar o caso da Chacina da Candelária sem mencionar J. G. F., por ter se tornado peça chave do episódio e do inquérito policial.

Ao julgar o Recurso Especial, foi aclarado que "o cerne da controvérsia passa pela ausência de contemporaneidade da notícia de fatos passados, que reabriu antigas feridas já superadas pelo autor e reacendeu a desconfiança da sociedade quanto à sua índole" (BRASIL, STJ, REsp 1.334.097/RJ, 2013, p. 11), havendo um conflito ente liberdade de imprensa, de informação e o direito ao esquecimento, sendo destacado que:

[...] a explícita contenção constitucional à liberdade de informação, fundada na inviolabilidade da vida privada, intimidade, honra, imagem e, de resto, nos valores da pessoa e da família, prevista no art. $220, \S 1^{\circ}$, art. 221 e no $\S 3^{\circ}$ do art. 222 da Carta de 1988, parece sinalizar que, no conflito aparente entre esses bens jurídicos de especialíssima grandeza, há, de regra, uma inclinação ou predileção constitucional para soluções protetivas da pessoa humana, embora o melhor equacionamento deva sempre observar as particularidades do caso concreto (BRASIL, STJ, REsp 1.334.097/ RJ, 2013, p. 12-13).

Nesse giro, o STJ posicionou-se no sentido que, apesar da liberdade de informação consubstanciar importante direito constitucional, deve ser contido pela proteção da pessoa humana, bem como pela proteção de sua dignidade (fundamento da República), devendo a análise ser feita no caso concreto.

Destaca-se, ainda, que a

[...] historicidade da notícia jornalística, em se tratando de jornalismo policial, há de ser vista com cautela. Há, de fato, crimes históricos e criminosos famosos; mas também há crimes e criminosos que se tornaram artificialmente históricos e famosos, obra da exploração midiática exacerbada e de um populismo penal satisfativo dos prazeres primários das multidões, que simplifica o fenômeno criminal às estigmatizadas figuras do "bandido" vs. "cidadão de bem" (BRASIL, STJ, REsp 1.334.097/ RJ, 2013, p. 13).

Neste sentido, em alguns casos, como este envolvendo J. G. F., a retratação ampla e sem restrições do crime, bem como das pessoas nele envolvidas "pode significar permissão de um segundo abuso à dignidade humana, simplesmente porque o primeiro já fora cometido no passado" (BRASIL, STJ, REsp 1.334.097/RJ, 2013, p. 13), sendo possível que se reconheça o direito ao esquecimento, na qualidade de um corretivo do ocorrido no passado.

Outro argumento apresentado, no acórdão, é de que

[...] o Direito estabiliza o passado e confere previsibilidade ao futuro por institutos bem conhecidos de todos: prescrição, decadência, perdão, anistia, irretroatividade da lei, respeito ao direito adquirido, ato jurídico perfeito, coisa julgada, prazo máximo 
para que o nome de inadimplentes figure em cadastros restritivos de crédito, reabilitação penal e o direito ao sigilo quanto à folha de antecedentes daqueles que já cumpriram pena (BRASIL, STJ, REsp 1.334.097/RJ, 2013, p.14).

Desta forma, se o próprio ordenamento jurídico se orienta com a finalidade de impedir que eternamente uma pessoa pague por seu erro, não seria adequada a lembrança constante do ocorrido, por parte da mídia, a qual potencialmente provocaria danos a parte envolvida.

Ainda, o "interesse público que orbita o fenômeno criminal tende a desaparecer na medida em que também se esgota a resposta penal conferida ao fato criminoso, a qual, certamente, encontra seu último suspiro, com a extinção da pena ou com a absolvição" (BRASIL, STJ, REsp 1.334.097/RJ, 2013, p.14). Logo, o interesse público se fixa no processo penal, que naturalmente é público, a fim de que haja uma fiscalização social da atuação do Estado, para o adequado cumprimento das disposições do ordenamento jurídico, mas, não se justifica, após uma absolvição, ou cumprimento de pena, que se continue a perseguir aquele que já foi submetido a aplicação das leis, que, em tese, são construídas por toda a sociedade.

Na decisão, o STJ entendeu, ainda, que não se inclui no direito ao esquecimento aqueles fatos genuinamente históricos, os quais serão analisados no caso concreto, devendo o interesse público e social permanecer no decurso do tempo, no entanto, naqueles casos em for possível a não vinculação de um envolvido, não se deve faze-la, preservando, neste caso, o seu direito ao esquecimento (BRASIL, STJ, REsp 1.334.097/RJ, 2013, p. 14). Assim, ao tratar do caso concreto, entendeu-se que a Chacina da Candelária é um fato histórico, no entanto a ocorrência poderia ter sido relatada sem envolver o nome e imagem de J. G. F., de modo que: "nem a liberdade de imprensa seria tolhida, nem a honra do autor seria maculada, caso se ocultassem o nome e a fisionomia do recorrido, ponderação de valores que, no caso, seria a melhor solução ao conflito" (BRASIL, STJ, REsp 1.334.097/RJ, 2013, p.15).

Inclusive, pode-se destacar que "a receptividade do homem médio brasileiro a noticiários desse jaez é apta a reacender a desconfiança geral acerca da índole do autor, o qual, certamente, não teve reforçada sua imagem de inocentado, mas sim a de indiciado" (BRASIL, STJ, REsp 1.334.097/RJ, 2013, p.15).

Deste modo, o STJ entendeu por não prover o recurso interposto pela TV Globo, mantendo a condenação em pagamento de $\mathrm{R} \$ 50.000,00$ (cinquenta mil reais), como indenização.

\subsection{Caso Aída Curi}

O Recurso Especial n. 1.335.153/RJ, de relatoria do Ministro Luis Felipe Salomão, decorre de ação de reparação de danos morais, materiais e à imagem, movida por três irmãos de Aída Curi, em face da TV Globo Ltda. (Globo Comunicações e Participações S.A.).

Os autores se identificam como os únicos irmãos vivos de Aída Curi, a qual, em 1958, foi vítima de homicídio, tendo repercussão nacional.

Os irmãos argumentam que a Tv Globo reabriu antigas feridas, veiculando novamente, através do programa "Linha Direta-Justiça" a vida de Aída Curi, o seu homicídio e os desdobramentos do crime, abordando um fato que fora esquecido pelo passar do tempo, além de explorar a imagem da irmã dos autores.

Os irmãos

[...] entendem que a exploração do caso pela emissora, depois de passados tantos anos, foi ilícita, tendo ela sido previamente notificada pelos autores para não fazê-lo, 


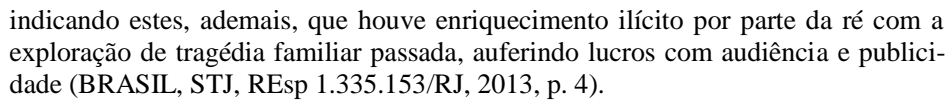

Assim, requereram a indenização por danos morais, em razão do sofrimento provocado ao reviverem os fatos do passado, bem como danos materiais e a imagem, pela exploração comercial do caso.

Em primeiro grau, os pedidos foram julgados improcedentes.

Na apelação, julgada pelo Tribunal de Justiça do Estado do Rio de Janeiro, entendeu-se pela ausência de dano. Argumentou-se no sentido de que é tutelado pela Constituição Federal o direito à livre expressão da atividade de comunicação, sendo cabível indenização na hipótese de se utilizar da imagem ou das informações para denegrir ou atingir a honra da parte retratada, ou a imagem for utilizada para fins comerciais. Destacou que a situação exposta já era de conhecimento público, sendo que nos cinquenta anos, desde o homicídio de Aída Curi, discutiu-se a temática, inclusive academicamente. Entendeu que a TV Globo cumpriu com sua função social de informar, alertar e abrir, o caso, para debate (RIO DE JANEIRO, TJRJ, AC 012330577.2004.8.19.0001, 2010, p.1).

Em seu voto, o Relator Desembargador Ricardo Rodrigues Cardozo apontou que "o esquecimento não é o caminho salvador para tudo. Muitas vezes é necessário reviver o passado para que as novas gerações fiquem alertadas e repensem alguns procedimentos de conduta do presente (RIO DE JANEIRO, TJRJ, AC 0123305-77.2004.8.19.0001, 2010, p. 4).

Ato contínuo, argumentou que, pelos dados nos autos, o uso do nome, da imagem, ou a reprodução dos acontecimentos não trouxe aumento do lucro da TV Globo. Assim, o recurso foi desprovido (RIO DE JANEIRO, TJRJ, AC 0123305-77.2004.8.19.0001, 2010, p. 1-2).

Dado isso, os irmãos apresentaram recurso especial, alegando, no mérito, "o direito ao esquecimento acerca da tragédia familiar pela qual passaram na década de cinquenta do século passado, direito esse que foi violentado pela emissora ré” (BRASIL, STJ, REsp 1.335.153/RJ, 2013, p.5).

O STJ entendeu que "o cerne da controvérsia passa pela ausência de contemporaneidade da notícia de fatos passados, a qual, segundo o entendimento dos autores, reabriu antigas feridas já superadas quanto à morte de sua irmã, Aída Curi, no distante ano de 1958" (BRASIL, STJ, REsp 1.335.153/RJ, 2013, p.7).

Ademais, ponderou-se que para além daqueles condenados que cumpriram pena e os absolvidos em processo criminal, também, teriam direito ao esquecimento a vítima e seus familiares, considerando que: "Caso contrário, chegar-se-ia à antipática e desumana solução de reconhecer esse direito ao ofensor [...] e retirá-lo dos ofendidos, permitindo que os canais de informação se enriqueçam mediante a indefinida exploração das desgraças privadas pelas quais passaram" (BRASIL, STJ, REsp 1.335.153/RJ, 2013, p. 7-8).

Em que pese existir este direito para os condenados que cumpriram pena, para os absolvidos em processo criminal, para a vítima e para os seus familiares, deve-se ponderar com relação a historicidade do fato, de modo que "em um crime de repercussão nacional, a vítima [...] frequentemente se torna elemento indissociável do delito, circunstância que, na generalidade das vezes, inviabiliza a narrativa do crime caso se pretenda omitir a figura do ofendido" (BRASIL, STJ, REsp 1.335.153/RJ, 2013, p. 8). Entendendo que seria inviável retratar o caso de Aída Curi, que entrou para o domínio público, sem retratar a vítima Aída Curi. 
O acórdão aponta, ainda, que a ponderação sobre o crime ser histórico ou não, deve se dar no caso concreto, podendo ser entendido, em alguns casos, que não se trata de um acontecimento histórico, mas mera e exacerbada exploração midiática, de modo que, se continuar essa exploração, poder-se-ia falar em um segundo abuso. Não se entendeu que o caso de Aída Curi trataria de uma artificiosidade da mídia, mas que se enquadraria em uma exceção de ampla publicidade, inerente a alguns crimes (BRASIL, STJ, REsp 1.335.153/RJ, 2013, p.8).

A decisão salienta, ainda, que

\begin{abstract}
[...] no caso de familiares de vítimas de crimes passados, que só querem esquecer a dor pela qual passaram em determinado momento da vida, há uma infeliz constatação: na medida em que o tempo passa e vai se adquirindo um "direito ao esquecimento", na contramão, a dor vai diminuindo, de modo que, relembrar o fato trágico da vida, a depender do tempo transcorrido, embora possa gerar desconforto, não causa o mesmo abalo de antes (BRASIL, STJ, REsp 1.335.153/RJ, 2013, p. 8).
\end{abstract}

Entende-se, neste sentido, que pelo fato da reportagem ter ido ao ar 50 (cinquenta) anos depois da morte de Aída Curi, chega-se à conclusão de não ter havido abalo psicológico apto a gerar responsabilidade civil, de modo que, o acolhimento do direito ao esquecimento, em detrimento da liberdade de imprensa, conferiria uma desproporcional agressão à liberdade (BRASIL, STJ, REsp 1.335.153/RJ, 2013, p. 8).

Com relação a imagem da falecida, entendeu-se que ela não foi utilizada de forma degradante ou desrespeitosa, bem como, não houve uso comercial da imagem.

Diante tudo o que foi apresentado, o STJ, também, negou acolhimento ao pedido de indenização, não dando provimento ao recurso.

\title{
6 A (IM)POSSIBILIDADE DE APLICAÇÃO DO DIREITO AO ESQUECI- MENTO
}

No que tange ao direito ao esquecimento, pode-se afirmar que ele existe e encontra a sua validade no ordenamento jurídico brasileiro, tanto pela Constituição Federal de 1988, a qual direciona inegável proteção ao ser humano, positivando o princípio da dignidade da pessoa humana, além de direitos fundamentais; quanto pelo Código Civil de 2002, o qual apresenta um capítulo para tratar dos direitos da personalidade, apontando critérios gerais, além de um rol não taxativo destes direitos ${ }^{13}$. Inclusive, como apresentado, o próprio STJ tem construído o entendimento de que o direito ao esquecimento é acolhido pelo ordenamento jurídico brasileiro.

Não obstante, resta analisar como o direito ao esquecimento pode efetivamente ser aplicado, tendo em vista que encontra barreira de determinadas tutelas constitucionais, como a liberdade de expressão, liberdade de imprensa, liberdade de informação. Além destas liberdades, pode-se apontar o direito à memória como outro contraponto ao direito ao esquecimento.

Para que se verifique qual direito deve prevalecer, é necessário a utilização da técnica de ponderação de interesses, que se manifestará, sempre, no caso concreto ${ }^{14}$, de modo que:

${ }^{13}$ Destarte, o Conselho de Justiça Federal, em sua IV Jornada de Direito Civil, aprovou o Enunciado 274: "Os direitos da personalidade, regulados de maneira não-exaustiva pelo Código Civil, são expressões da cláusula geral de tutela da pessoa humana, contida no art. $1^{\circ}$, III, da Constituição (princípio da dignidade da pessoa humana). Em caso de colisão entre eles, como nenhum pode sobrelevar os demais, deve-se aplicar a técnica da ponderação" (BRASIL, 2006, p. 1-2).

14 Anderson Schreiber (2018, p. 72) alerta que "toda ponderação, como se sabe, deve ser efetuada a luz da hipótese fática subjacente. Assim, deve-se resistir à tentação de traçar parâmetros supostamente aplicáveis a todos os casos em que 


\begin{abstract}
Não é possível dizer, de modo prévio, qual princípio irá prevalecer. A resposta depende da ponderação dos valores relevantes nas circunstâncias específicas. Nossa ordem jurídica não tolera a censura; por outro lado, também não aceita que se esvazie o princípio que resguarda a intimidade e a vida privada das pessoas. (BRAGA NETTO, 2016, p. 404).
\end{abstract}

Destarte, caberá ao intérprete analisar todas as circunstâncias do caso concreto, verificar quais direitos encontram-se em conflito, bem como aferir qual deve prevalecer, considerando não só a norma redigida, mas, também, os princípios, podendo encontrar na doutrina contribuições para sua argumentação. Nesse giro, Luiz Roberto Barroso (2004, p.5) defende que:

\begin{abstract}
A moderna interpretação constitucional diferencia-se da tradicional em razão de alguns fatores: a norma, como relato puramente abstrato, já não desfruta de primazia; o problema, a questão tópica a ser resolvida passa a fornecer elementos para sua solução: o papel do intérprete deixa de ser de pura aplicação da norma preexistente e passa a incluir uma parcela de criação do Direito do caso concreto. E, como técnica de raciocínio e de decisão, a ponderação passa a conviver com a subsunção. Para que se legitimem suas escolhas. o intérprete terá de servir-se dos elementos da teoria da argumentação, para convencer os destinatários do seu trabalho de que produziu a solução constitucionalmente adequada para a questão que lhe foi submetida.
\end{abstract}

Assim, verificada a existência do direito ao esquecimento, o que pode se dar, conforme ficou decidido no acórdão do REsp n. 1.335.153/RJ, em benefício do condenado que já cumpriu toda a sua pena, daquele que foi absolvido no processo criminal, da vítima e de seus familiares (BRASIL, STJ, REsp 1.335.153/RJ, 2013, p. 7-8), passa-se para uma etapa de compatibilização do direito ao esquecimento com as liberdades de informação, de expressão e de imprensa.

Deste modo, deve-se analisar:

[...] em primeiro lugar se a notícia traduz interesse público, isto é, se contém conteúdo informativo ou educativo ou se se reduz à mera especulação ou mexerico. $\mathrm{O}$ sacrifício de direitos fundamentais da pessoa humana deve estar estritamente condicionado a uma real vantagem da coletividade, que se realiza no âmbito de um direito de informação adequadamente disciplinado. Com efeito, tem-se perfeita consciência da natureza não neutra da informação, a qual em uma sociedade democrática afigurase sempre como uma mensagem política. A divulgação de fatos lesivos de direitos individuais, portanto, somente se justifica no reconhecimento desta função, qual seja a capacidade de condicionar a gestão da polis sob um duplo aspecto: i) orientar a opinião pública e sugerir regras úteis de experiência; ii) chamar a atenção dos poderes públicos para problemas importantes da coletividade (BODIN DE MORAES, 2013, p. 4-5).

É necessário que seja verificado se com determinada divulgação de fato do passado buscase realmente abordar um assunto de interesse público ou realizar um espetáculo em troca de audiência. Questão que só poderá se dar no caso concreto, como fora apontado nos episódios da Chacina da Candelária e de Aída Curi, hipóteses em que ficou reconhecido que os casos eram envoltos de um interesse público, muito em razão da violência empregada, provocando repúdio de todo o corpo social.

Ademais, outra forma de restar claro que um fato apresenta interesse público, são aquelas situações englobadas pelo direito à memória, que tende a explorar uma verdade histórica, a fim de identificar que aqueles fatos são relevantes para um determinado povo, como se vê na Ditadura Militar, em processos políticos como impeachment, condenações criminais de políticos, dentre outras situações, que constroem uma identidade de determinado povo.

se contraponham direito ao esquecimento e liberdade de informação. Cada hipótese fática apresenta circunstâncias relevantes distintas, conforme os diversos interesses que se conjugam concretamente. A título de auxílio ao julgador, contudo, é possível formular parâmetros específicos para certos gêneros mais comuns de situações fáticas que ensejam colisão entre direito ao esquecimento e liberdade de informação". 
Não se pode deixar de destacar que em se tratando de crimes, sempre haverá um interesse público, em especial, no que tange o processo penal, o qual pode ser acompanhado pelos atores sociais, inclusive contribuindo para que haja, por parte do Estado, uma aplicação adequada das disposições legais. No entanto, são raríssimos casos em que o destaque do fato criminoso assume volume suficiente para que mesmo após a condenação, cumprimento de pena, se continue a abordar o acontecimento, que, nesta hipótese, descartados os casos de sensacionalismo da mídia, se torna genuinamente histórico, por marcar a sociedade da época e ser importante que a sociedade do futuro tenha conhecimento.

Portanto, o STJ firmou entendimento nos dois casos apresentados, que o interesse público deve prevalecer sobre o direito ao esquecimento e todo o seu embasamento civil e constitucional. No entanto, como a análise é casuística, deve-se verificar se determinado fato de interesse público poderia ter sido contado sem que houvesse a exposição de determinada pessoa, a fim de garantir o seu direito ao esquecimento e consequente proteção de sua dignidade, sem afastar a liberdade de explorar midiaticamente aquele acontecimento. Isto aconteceu no caso da Chacina da Candelária, em que a exposição do autor da ação era desnecessária, de modo que se podia expor e debater um assunto de interesse público sem provocar lesões àquele que já havia sido absolvido dos crimes que fora acusado.

Enfim, destaca-se que ponderar o direito ao esquecimento com outros direitos e garantias constitucionais não é tarefa fácil, nem pode ser esgotado, tendo em vista que de uma situação para outra se vê distinções, que desafiam o intérprete a verificar o limite do direito ao esquecimento. Contudo, deve o magistrado utilizar de toda a argumentação possível para decidir, considerando as disposições da Constituição Federal, do Código Civil e demais leis, mas, também, considerar o estudo e o direcionamento da doutrina, a fim de se convencer entre eventual acolhimento de um pedido ou não.

\section{CONSIDERAÇÕES FINAIS}

A sociedade da informação constitui um novo e atual modelo de organização do corpo social. A interação entre homem e tecnologia apontam para o auge da comunicação, de modo a se ter acesso, inclusive, em aparelhos compactos, a uma enorme carga informativa, que se distribui graças a Internet, se manifestando na forma de redes sociais, sites de notícias, visualizadores de vídeo, sem que se tenha, ainda, abandonado meios mais antigos de comunicação de massa, como o rádio, a televisão e o jornal.

Neste cenário, é necessário que o ordenamento jurídico esteja apto para evitar e repreender eventuais lesões as pessoas, que se encontram vulneráveis a serem expostas, podendo sofrerem feridas em seus direitos fundamentais e da personalidade, como à imagem, à honra, à privacidade.

Como uma possibilidade de ser violado, acentua-se a discussão sobre o direito ao esquecimento, que surge com a ideia de evitar que determinada pessoa, que já cumpriu a pena de uma condenação criminal, que foi absolvida de um processo penal, que foi vítima de determinado fato ou seus familiares, seja atingida por um episódio longínquo, contra a sua vontade, podendo provocar-lhe danos psíquicos e materiais.

Ocorre que embora o direito ao esquecimento se enquadre como um direito da personalidade, que possui amparo da Constituição Federal, sobretudo, no que tange a princípios e direitos 
fundamentais, é necessário destacar que se tem contraposto por outros direitos e garantias constitucionais, particularmente, a liberdade de imprensa, de expressão, de informação, a ponto de haver a necessidade da existência da ponderação no caso concreto.

A liberdade de expressão, de imprensa, de informação não podem sofrer censura prévia, ou seja, é inadmissível que se diga o que não se pode ser falado ou transmitido. Não obstante, na hipótese de haver violação do direito alheio, é cabível a análise do caso concreto para aplicação dos instrumentos presentes no Estado Democrático de Direito, como é o caso do direito ao esquecimento.

A ideia do direito ao esquecimento, mas também dessas liberdades, deve ser de que não são direitos absolutos, muito pelo contrário, encontram seus limites na própria Constituição, sendo que, o magistrado ao julgar deverá realizar uma interpretação sistemática, a fim de verificar se determinada liberdade pode violar, por exemplo, a dignidade da pessoa humana.

Nesse cenário, o interesse público apresenta-se como pressupostos fundamental ao desate da controvérsia envolvendo o direito ao esquecimento e as liberdades de expressão, de informação e de imprensa. Logo, o interesse público assume, a princípio, maior relevância no ordenamento jurídico, de modo que havendo o interesse público, não se justifica aplicar o direito ao esquecimento, a menos que a parte afetada seja meramente acessório do fato, circunstância em que se poderia resguardar o interesse público, bem como as liberdades de expressão, de informação e de imprensa, sem violar o direito ao esquecimento.

O direito ao esquecimento, ainda, encontra-se em construção pela doutrina e jurisprudência, não só pelo fato de estar pendente de julgamento no Supremo Tribunal Federal, mas muito em razão de sua complexidade e do contexto social ao qual se insere. Ademais, os limites e contornos de seu campo de incidência e discussões são extensos, não se restringindo, por exemplo, a casos de exposição na televisão, alcançando circunstâncias mais obscuras, como possíveis violações deste direito nos meios de comunicação de massa e na Internet.

Em que pese restar claro o fato de que não se trata de um direito absoluto, a sua abordagem, bem como o seu fundamento, em especial a tutela da dignidade da pessoa humana, direito à honra, à privacidade, à imagem, revelam sua relevância para sociedade da informação, que demanda que os atores sociais desenvolvam um uso adequado das tecnologias e meios de comunicação disponíveis, para exercer suas liberdades (expressão, informação e imprensa), porém, compatibilizando seu exercício com os preceitos e valores constitucionais vigentes no Estado Democrático de Direito.

\section{REFERÊNCIAS}

ALMEIDA, José Luiz Gavião de; VEDOVATO, Luis Renato; SILVA, Marcelo Rodrigues da. A identidade pessoal como direito fundamental da pessoa humana e algumas de suas manifestações na ordem jurídica brasileira. Revista de Direito Civil Contemporâneo, São Paulo, ano 5, vol. 14, p. 33-70, jan./mar. 2018.

AZEVEDO, Antonio Junqueira. Caracterização Jurídica da Dignidade da Pessoa Humana. Revista USP, São Paulo, n. 53, p. 90-101, mar./maio 2002. Disponível em: https://www.revistas.usp.br/revusp/article/view/33189/35927. Acesso em: 29 abr. 2020

BARRETO JÚNIOR, Irineu Francisco; SAMPAIO, Vinícius Garcia Ribeiro; GALLINARO, Fábio. Marco civil da internet e o direito à privacidade na sociedade da informação. Direito, Estado 
e Sociedade, Rio de Janeiro, n. 52, p. 114-133, jan./jun. 2018. Disponível em: http://direitoestadosociedade.jur.puc-rio.br/media/art\%205\%20direito\%2052.pdf. Acesso em: 24 nov. 2019.

BARROSO, Luís Roberto. A dignidade da pessoa humana no direito constitucional contemporâneo: a construção de um conceito jurídico à luz da jurisprudência mundial. Tradução: Humberto Laport de Mello. Belo Horizonte: Fórum, 2014. Título original: Here, there, and everywhere: human dignity in contemporary law and in the transnational discourse.

BARROSO, Luís Roberto. Colisão entre liberdade de expressão e direitos da personalidade. Critérios de ponderação. Interpretação constitucionalmente adequada do código civil e da lei de imprensa. Revista de Direito Administrativos, Rio de Janeiro, v. 235, p. 1-36, jan./mar. 2004. Disponível em: http://bibliotecadigital.fgv.br/ojs/index.php/rda/article/download/45123/45026. Acesso em: 24 jan. 2020.

BODIN DE MORAES, Maria Celina. Honra, liberdade de expressão e ponderação. Civilistica.com, Rio de Janeiro, ano 2, n. 2, p. 1-17, abr./jun. 2013. Disponível em: https://civilistica.emnuvens.com.br/redc/article/view/89/59. Acesso em: 23 jan. 2020.

BRAGA NETTO, Felipe Peixoto. Imagem e imprensa na sociedade em rede: conexões temáticas na busca de critérios constitucionalmente consistentes de ponderação. In: SAMPAIO, José Adércio Leite (Coord.). Liberdade de expressão no século XXI. Belo Horizonte: Del Rey, 2016, p. 397-438.

BRAGA NETTO, Felipe Peixoto. Novo manual de responsabilidade civil. Salvador: Ed. JusPodivm, 2019.

BRASIL. [Constituição (1988)]. Constituição da República Federativa do Brasil de 1988. Brasília, DF: Presidência da República, [2019]. Disponível em: http://www.planalto.gov.br/ccivil_03/constituicao/constituicao.htm. Acesso em: 13 dez. 2019.

BRASIL. IV Jornada de Direito Civil. Enunciado n ${ }^{\circ}$ 274. Coordenador Geral Ministro Ruy Rosado de Aguiar. Brasília: Conselho de Justiça Federal, 2006, p. 1-2. Disponível em: https:// www.cjf.jus.br/cjf/CEJ-Coedi/jornadas-cej/IV\%20JORNADA\%20DE\%20DIREITO\%20CIVIL\%202013\%20ENUNCIADOS\%20APROVADOS.pdf/at download/file. Acesso em: 23 dez. 2019.

BRASIL. Superior Tribunal de Justiça (4. Turma). Recurso Especial 1.334.097/RJ. Recorrente: Globo Comunicações E Participações S/A. Recorrido: Jurandir Gomes De França Relator: Ministro Luis Felipe Salomão, 28 maio 2013. Disponível em: https://ww2.stj.jus.br/processo/revista/documento/mediado/?componente $=I T A \&$ sequencial $=1239004 \&$ num registro $=$ 201201449107\&data=20130910\&formato=PDF. Acesso em: 05 ago. 2019.

BRASIL. Superior Tribunal de Justiça (4. Turma). Recurso Especial 1.335.153/RJ. Recorrente: Nelson Curi e outros. Recorrido: Globo Comunicação E Participações S/A. Relator: Ministro Luis Felipe Salomão, 28 maio 2013. Disponível em: https://ww2.stj.jus.br/processo/revista/documento $/$ mediado $/$ ?componente $=I T A \&$ sequencial $=1237428 \&$ num registro $=201100574280 \&$ data=20130910\&formato=PDF. Acesso em: 05 ago. 2019.

BRASIL. Supremo Tribunal Federal. Medida Cautelar na Suspensão de Liminar 1.248/RJ. Requerente: Ministério Público Federal. Requerido: Presidente do Tribunal de Justiça do Estado do Rio de Janeiro. Relator: Ministro Presidente Dias Toffoli, 8 set. 2019. Disponível em: http:// portal.stf.jus.br/processos/downloadPeca.asp?id=15341063935\&ext=.pdf. Acesso em: 22 dez. 2020. 
BRASIL. VI Jornada de Direito Civil. Enunciado no 531. Coordenador Geral Ministro Ruy Rosado de Aguiar. Brasília: Conselho de Justiça Federal, 2013, p. 1. Disponível em: https:// www.cjf.jus.br/cjf/CEJ-Coedi/jornadas-cej/enunciados-vi-jornada/at_download/file. Acesso em: 12 ago. 2019.

CAVALIERI FILHO, Sergio. Programa de responsabilidade civil. 13. ed. São Paulo: Atlas, 2019.

COLNAGO, Cláudio de Oliveira Santos. Liberdade de expressão na internet. Salvador: Editora Juspodivm, 2019.

COMPARATO, Fábio Konder. A afirmação histórica dos direitos humanos. 6. ed. São Paulo: Saraiva, 2008.

CONSALTER, Zilda Mara. Direito ao esquecimento: proteção da intimidade e ambiente virtual. Curitiba: Juruá, 2017.

CORDEIRO, Carlos José; PAULA NETO, Joaquim José. A concretização de um novo direito da personalidade: o direito ao esquecimento. Civilistica.com, Rio de Janeiro, ano 4, n. 2, p. 1 22, 2015. Disponível em: http://civilistica.com/wp-content/uploads/2015/12/Cordeiro-e-PaulaNeto-civilistica.com-a.4.n.2.20151.pdf. Acesso em: 05 ago. 2018.

DELPUPO, Michely Vargas. O direito à privacidade, à intimidade e à imagem na internet. In: DONNINI, Rogério (Coord). ZANETTI, Andrea Cristina (Org.). Risco, dano e responsabilidade civil. Salvador: Editora JusPodivm, 2018, p. 185-206.

EHRHARDT JÚNIOR, Marcos; ACIOLI, Bruno de Lima. Privacidade e os desafios de sua compreensão contemporânea: do direito de ser deixado em paz ao direito ao esquecimento. In: MENEZES, Joyceane Bezerra de; TEPEDINO, Gustavo (Coord.). Autonomia privada, liberdade existencial e direitos fundamentais. Belo Horizonte: Fórum, 2019, p. 151-166.

FACHIN, Luiz Edson. Trinta anos da Constituição Federal: desafios constitucionais de hoje e propostas para os próximos trinta anos. Revista de Direito Civil Contemporâneo, São Paulo, ano 6, v. 8, p. 363-370, jan./mar. 2019.

FARIAS, Cristiano Chaves de; BRAGA NETTO, Felipe Peixoto; ROSENVALD, Nelson. Novo tratado de responsabilidade civil. 4. ed. São Paulo: Saraiva Educação, 2019.

FARIAS, Cristiano Chaves de; ROSENVALD, Nelson. Curso de direito civil: parte geral e LINDB. Vol. 1. 14. ed. Salvador: Juspodivm, 2016.

FERNANDES, Bernardo Gonçalves. Curso de Direito Constitucional. 8. ed. Salvador: JusPODIVM, 2016.

FIUZA, César. Perigos de uma hermenêutica civil-constitucional. Revista da Faculdade Mineira de Direito, Belo Horizonte, v. 11, n. 22, p. 65-67, $2^{\circ}$ sem. 2008.

GODOY, Claudio Luiz Bueno de. A Liberdade de Imprensa e os Direitos da Personalidade. 3. ed. São Paulo: Atlas, 2015.

GOUVÊA, Eduardo Mingorance de Freitas. Privacidade e Internet: o direito de não ser exposto na rede. Revista de Direito Privado, São Paulo, ano 20, v. 97, p. 19-44, jan./fev. 2019.

GUSTIN, Miracy Barbosa de Sousa; DIAS, Maria Tereza Fonseca. (Re)pensando a pesquisa jurídica: teoria e prática. 4. ed. Belo Horizonte: Del Rey, 2013. 
HIRATA, Alessandro. O Facebook e o direito à privacidade. Revista de Informação Legislativa, Brasília, ano 51, n. 201, p. 17-27, jan./mar. 2014. Disponível em: https://www12.senado.leg.br/ril/edicoes/51/201/ril_v51_n201_p17.pdf. Acesso em: 14 nov. 2019.

LIMA, Taisa Maria Macena de; SÁ, Maria de Fátima Freire de. Novas tecnologias: o impacto da internet na vida da criança e do adolescente. In: BRAGA NETTO, Felipe Peixoto; SILVA, Michael César (Orgs.). Direito Privado e contemporaneidade: desafios e perspectivas do direito privado no século XXI. vol. II. Rio de Janeiro: Lumen Juris, 2018, p. 29-46.

MARINHO JÚNIOR, Jânio Urbano. Responsabilidade civil de provedores de internet, websites e gestores de aplicativos de redes sociais. Revista de Direito Privado, São Paulo, ano 19, v. 91, p. 17-38, julho 2018 .

MARQUES, Gil da Costa; CRESPO, Marcelo Xavier de Freitas. Um panorama sobre a sociedade da informação: o cloud computing e alguns aspectos jurídicos no ambiente digital. In: MENDES, Gilmar Ferreira; WOLFGANG SARLET, Ingo; COELHO, Alexandre Zavaglia P. (Coords.). Direito, inovação e tecnologia. v. 1. São Paulo: Saraiva, 2015, p. 123-138.

MORATO, Antonio Carlos. Quadro geral dos direitos da personalidade. Revista da Faculdade de Direito da Universidade de São Paulo, São Paulo, v. 106/107, p. 121-158, jan./dez. 2011/ 2012. Disponível em: http://www.revistas.usp.br/rfdusp/article/viewFile/67941/70549. Acesso em: 05 ago. 2018.

MOREIRA, Rodrigo Pereira; ALVES, Rubens Valtecides. Direito ao esquecimento e o livre desenvolvimento da personalidade da pessoa transexual. Revista de Direito Privado, São Paulo, ano 16, v. 64, p. 81-102, out./dez. 2015.

MOREIRA, Rodrigo Pereira; MEDEIROS, Jaquelaine Souza. Direito ao esquecimento: entre a sociedade da informação e a civilização do espetáculo. Revista de Direito Privado, São Paulo, ano 17, v. 70, p. 71-98, out. 2016.

NEVES, Thiago Ferreira Cardoso. Autonomia privada e privacidade nas redes sociais: renunciabilidade e responsabilidade por danos. Rio de janeiro: LMJ Mundo Jurídico, 2019.

PINHEIRO, Denise; MARTINS NETO, João dos Passos. A desconstrução do direito ao esquecimento no direito brasileiro e a contribuição da jurisprudência francesa. Revista de Direito Civil Contemporâneo, São Paulo, ano 5, v. 15, p. 31-71, abr./jun. 2018.

POMPEU, Gina Vidal Marcílio; POMPEU, Inês Mota Randal. Liberdade de expressão e informação em face dos direitos da personalidade: análise com base na ADI n ${ }^{\circ}$ 4.815. In: MENEZES, Joyceane Bezerra de; TEPEDINO, Gustavo (Coord.). Autonomia privada, liberdade existencial e direitos fundamentais. Belo Horizonte: Fórum, 2019, p. 269-283.

RIO DE JANEIRO. Tribunal de Justiça do Estado do Rio de Janeiro. Apelação Cível 2008.001.48862. Apelante: Jurandir Gomes de França. Apelado: Globo Comunicações e Participações S/A. Relator: Desembargador Renato Gusmão Alves De Brito Neto, 13 nov. 2008. Disponível em: http://www1.tjri.jus.br/gedcacheweb/default.aspx?UZIP=1\&GEDID= 0003EED189BD70D943FB4DF9D32CC4F954CF62C40213455F. Acesso em: 05 ago. 2019.

RIO DE JANEIRO. Tribunal de Justiça do Estado do Rio de Janeiro. Apelação Cível 012330577.2004.8.19.0001. Apelante: Nelson Curi e outros. Apelado: Globo Comunicação e Participações S.A. Relator: Desembargador Ricardo Rodrigues Cardozo, 17 ago. 2010. Disponível em: http://www1.tjrj.jus.br/gedcacheweb/default.aspx?UZIP=1\&GEDID=

0003D8BBC1BD31CB5CA33BB5D7E0C8B8726979C4024C1E11. Acesso em: 05 ago. 2019. 
ROCHA, Maria Vital da; LOPES, Lidiane Moura. A aplicação da teoria do "hate speech" nas decisões do STF: um Estudo de casos. Revista Jurídica FA7, Fortaleza, v. 13, n. 2, p. 71-82, jul./dez. 2016. Disponível em: https://periodicos.uni7.edu.br/index.php/revistajuridica/article/ view/64/53. Acesso em: 21 fev. 2020.

SAMPAIO, José Adércio Leite. Direito à intimidade e a vida privada: uma visão jurídica da sexualidade, da família, da comunicação e informações pessoais, da vida e da morte. Belo Horizonte: Del Rey, 1998.

SARMENTO, Daniel. Dignidade da pessoa humana: conteúdo, trajetórias e metodologia. Belo Horizonte: Fórum, 2016

SCHREIBER, Anderson. Direito ao esquecimento. In: SALOMÃO, Luis Felipe; TARTUCE, Flávio (Coords.). Direito Civil: diálogos entre a doutrina e a jurisprudência. São Paulo: Atlas, 2018, p. 65-82.

SCHREIBER, Anderson. Direitos da Personalidade. 3. ed. São Paulo: Editora Atlas, 2014.

SCHREIBER, Anderson. Responsabilidade civil por violação do direito ao esquecimento. In: EHRHARDT JÚNIOR, Marcos; CORTIANO JUNIOR, Eroulths (Coords.). Transformações no Direito Privado nos 30 anos da Constituição: estudos em homenagem a Luiz Edson Fachin. Belo Horizonte: Fórum, 2019, p. 529-543.

SCHULMAN, Gabriel. www.privacidade-em-tempos-de-internet.com: o espaço virtual e os impactos reais à privacidade das pessoas. In: TEPEDINO, Gustavo; TEIXEIRA, Ana Carolina Brochado; ALMEIDA, Vitor (Coords.). O Direito Civil entre o sujeito e a pessoa: estudos em homenagem ao professor Stefano Rodotà. Belo Horizonte: Fórum, 2016, p. 333-360.

TEFFÉ, Chiara Spadaccini de. A proteção dos direitos da personalidade no ordenamento civilconstitucional. In: TEPEDINO, Gustavo; OLIVA, Milena Donato (Coords.). Teoria geral do Direito Civil: questões controvertidas. Belo Horizonte: Fórum, 2019, p. 91-119.

TEPEDINO, Gustavo. Temas de direito civil. 4. ed. Rio de Janeiro: Renovar, 2008.

WOLFGANG SARLET, Ingo. Dignidade (da pessoa) humana e direitos fundamentais na Constituição Federal de 1988. 10. ed. Porto Alegre: Livraria do Advogado Editora, 2015.

WOLFGANG SARLET, Ingo. Direitos fundamentais e Direito Privado: notas sobre a influência dogmática alemã dos direitos fundamentais, em especial a contribuição de Claus-Wilhelm Canaris, no direito brasileiro. Revista de Direito Civil Contemporâneo, São Paulo, ano 4, v. 12, p. 63-88, jul.-set. 2017.

Recebido em: 28 fev. 2020.

Aceito em: 4 maio 2020. 